Article

\title{
Saussurea lappa Exhibits Anti-Oncogenic Effect in Hepatocellular Carcinoma, HepG2 Cancer Cell Line by Bcl-2 Mediated Apoptotic Pathway and Mitochondrial Cytochrome C Release
}

\author{
Amal A. Alotaibi ${ }^{1}$ (D), Asmatanzeem Bepari ${ }^{1, *(\mathbb{D})}$, Rasha Assad Assiri ${ }^{1}$, Shaik Kalimulla Niazi ${ }^{2, *}$, \\ Sreenivasa Nayaka ${ }^{3} \mathbb{D}$, Muthuraj Rudrappa ${ }^{3} \mathbb{D}$, Shashiraj Kareyellapa Nagaraja ${ }^{3}$ \\ and Meghashyama Prabhakara Bhat ${ }^{3}$ (D)
}

1 Department of Basic Health Sciences, College of Medicine, Princess Nourah Bint Abdulrahman University, Riyadh 11671, Saudi Arabia; AMAAlotaibi@pnu.edu.sa (A.A.A.); RAAssiri@pnu.edu.sa (R.A.A.)

2 Department of Preparatory Health Sciences, Riyadh Elm University, Riyadh 12611, Saudi Arabia

3 Department of Studies in Botany, Karnatak University, Dharwad 580003, India; sreenivasankud@gmail.com (S.N.); rmuthuraj20@gmail.com (M.R.); rajscbz@gmail.com (S.K.N.); meghubhat09@gmail.com (M.P.B.)

* Correspondence: ambepari@pnu.edu.sa (A.B.); kalimullaniazi@gmail.com (S.K.N.)

check for updates

Citation: Alotaibi, A.A.; Bepari, A.; Assiri, R.A.; Niazi, S.K.; Nayaka, S.; Rudrappa, M.; Nagaraja, S.K.; Bhat, M.P. Saussurea Lappa Exhibits Anti-Oncogenic Effect in Hepatocellular Carcinoma, HepG2 Cancer Cell Line by Bcl-2 Mediated Apoptotic Pathway and Mitochondrial Cytochrome C Release. Curr. Issues Mol. Biol. 2021, 43, 1114-1132. https://doi.org/10.3390/ cimb43020079

Academic Editor: Luca Falzone

Received: 15 August 2021

Accepted: 3 September 2021

Published: 8 September 2021

Publisher's Note: MDPI stays neutral with regard to jurisdictional claims in published maps and institutional affiliations.

Copyright: (C) 2021 by the authors. Licensee MDPI, Basel, Switzerland. This article is an open access article distributed under the terms and conditions of the Creative Commons Attribution (CC BY) license (https:// creativecommons.org/licenses/by/ $4.0 /)$.
Abstract: Background and Objectives: Saussurea lappa (S. lappa) is an important species of the Asteraceae family with several purposes in traditional medicine. This study intended to explore the cytotoxic effect of S. lappa on HepG2 cancer cell proliferation. Materials and Methods: The effects of an S. lappa n-butanol extract on the induction of apoptosis were investigated by flow cytometry and mitochondrial cytochrome C-releasing apoptosis assay. Additionally, real-time PCR was employed to confirm apoptosis initiation. Further, qualitative estimation of the active constituent of S. lappa was done by gas chromatography-mass spectroscopy (GC-MS). Results: The cell viability study revealed that the n-butanol extract of $S$. lappa demonstrated potent cytotoxicity against HepG2 cancer cells, with an IC50 value of $56.76 \mu \mathrm{g} / \mathrm{mL}$. Cell morphology with dual staining of acridine orange (AO)-ethidium bromide (EB) showed an increase in orange/red nuclei due to cell death by S. lappa n-butanol extract compared to control cells. Apoptosis, as the mode of cell death, was also confirmed by the higher release of cytochrome $C$ from mitochondria, the increased expression of caspase- 3 and bax, along with down regulation of Bcl-2. Conclusion: These findings conclude that S. lappa is a cause of hepatic cancer cell death through apoptosis and a potential natural source suggesting furthermore investigation of its active compounds that are responsible for these observed activities.

Keywords: Saussurea lappa; HepG2; anticancer; apoptosis; cytochrome C release; Bcl-2

\section{Introduction}

Hepato-cellular cancer (HCC) is one of the most prevalent lethal malignancies, accounting for 626,000 new cases per year worldwide [1]. The five-year survival rate of HCC patients after surgery is about 20-30\%. It is frequently diagnosed at an advanced stage with metastasis or with progression after locoregional therapy and has a high mortality rate, owing to the underlying liver disorder, and there is paucity of effective therapeutic options [2,3]. Up to now, sorafenib, which inhibits multiple receptor tyrosine kinases (RTKs), especially VEGF-R2/3 (vascular endothelial growth factor-receptor), plateletderived growth factor- $\beta$ (PDGFR- $\beta$ ), and raf kinase, is the only useful chemotherapeutic agent in managing unresected HCC [4]. It increases the average survival time by three months in patients with late-stage HCC. The common adverse effects seen with sorafenib therapy are diarrhea, fatigue, weight loss, and hand-foot syndrome. Although it lengthens the median survival time with limited side effects in these patients, the development of 
resistance to sorafenib is the bottleneck in extending the overall survival time for HCC patients along with its high cost, which are significant restrictions on its use [5]. Therefore, to discover novel drugs is an urgent work for the treatment of HCC.

For a long time, natural products have served as important sources of novel lead structures for the discovery of anticancer agents as their diverse 'drug-like' structure and 'biologically-friendly' molecular qualities [6,7]. Nearly 73 clinically-approved anticancer drugs are plant-derived agents, according to a recent analysis, which includes some established agents, such as vinblastine, etoposide, paclitaxel, and topotecan, which are used in lung cancers, advanced breast cancer, ovarian carcinoma, testicular tumors, and Hodgkin's and other lymphomas [8].

Saussurea lappa (S. lappa), belonging to the family Asteraceae and is one of the bestknown species within its genus; it is a perennial, aromatic, and medicinal plant [9]. It is inherent to India and Pakistan and has been farmed in Southwest China. Its dried root has been utilized since ancient times as a traditional remedy of various illnesses and diseases, such as asthma, bronchitis, ulcer, and stomach diseases in Asia, including Korea and China [10]. Sesquiterpene lactones are found in members of the Asteraceae family that belong to class of terpenoid compounds. Terpenoids are in the form of several oxygencontaining derivatives, including alcohols, aldehydes, carboxylic acids, ketones, esters, and glycosides, which consist of numerous isoprene structural units such as monoterpene (C10), sesquiterpene (C15), diterpene (C20), triterpene (C30), tetraterpene (C40), and polyterpene (C > 40). They have good cytotoxic activity and have the potential to be leading compounds to innovate efficient and safe anticancer drugs [11].

Perillyl alcohol is a monocyclic monoterpene mainly present in the essential oils of medicinal plants, and it displayed high cytotoxic activity against OVCAR-8, HCT-116, and SF-295 human tumor cell lines using the MTT assay. The cell growth inhibition percentage values were 90.92-95.82\% [12]. Research has shown that ursolic acid activates cell apoptosis in prostate cancer through rho-associated protein kinase/phosphatase and tensin homolog-mediated mitochondrial translocation of cofilin-1 [13]. Cucurbitacin is a class of tetracyclic triterpenoids that also have antitumor activity [14]. Zhu et al. demonstrated that furanodiene, which is a terpenoid isolated from Rhizoma curcumae, produced anticancer effects through ROS production, anti-angiogenesis, apoptosis induction, and DNA strand breaks in MCF-7 human breast cancer cells and JF 305 pancreatic cell lines when transplanted into zebrafish [15].

The terpenoids can also be sub-divided into several main classes including Germacranolide, Guaianolides, Eudesmanolides, Heliangolides, etc. [16] The chief and bioactive components of Saussurea lappa are found to be sesquiterpenes and sesquiterpene lactones, including costunolide and dehydrocostus lactone, which belong to the germacranolides series and are described to produce cell death in some tumor cells $[17,18]$ and therefore can be effective against HCC cell lines.

Earlier in vitro cell culture studies have shown that S. lappa has antiulcer, antiinflammatory [19], and anti-hepatitis B virus activity, which is very important for the prevention of liver cancer, as well as hepatoprotective activity [20]. Additionally, S. lappa inhibits the growth of several types of cancer cells of neuroblastoma [21], lung cancer [22], breast cancer [23], and prostate cancer [24]. Therefore, S. lappa extract and its main bioactive constituents could be potential drug candidates for the treatment of HCC. In this study, we investigated the in vitro anti-cancer property of $S$. lappa extract against the hepatocellular carcinoma cell line, HepG2, along with its mechanism of cell death and qualitative estimation of its active constituent.

Objectives of the study:

The main aim of the study was to evaluate the anticancer potential of the root of Saussurea lappa extract against hepatocellular carcinoma using the in vitro method and characterization of possible bioactives from the root of $S$. lappa. Therefore, the following aspects of the root of $S$. lappa were planned and investigated: 
(a) Determination of various pharmacognostical parameters of the root of $S$. lappa including preparation of chloroform, n-butanol, and ethyl acetate extract fractions from the root of $S$. lappa and their physicochemical testing.

(b) Gas chromatography-mass spectroscopy (GC-MS) analysis of the different extracts.

(c) Evaluation of the anticancer activity of n-butanol S. lappa extract by employing the in vitro cytotoxic assay method (MTT assay) against HepG2 cell lines.

(d) Exploring mechanism of action of n-butanol S. lappa extract against HepG2 cell lines using double staining with acridine orange (AO)-ethidium bromide (EB), the cytochrome $\mathrm{C}$ release apoptosis assay, and gene expression studies.

\section{Materials and Methods}

Ethics approval was granted before the start of the study by the Institutional Review Board of Princess Nourah bint Abdulrahman University with IRB log number, 19-0276.

\subsection{Collection and Preparation of Plant Root Extract}

Saussurea lappa roots were collected from the local herbal market Dharwad, Karnataka, India and processed to remove the impurities. Plant authentication was confirmed by the Department of Botany, Karnatak University Dharwad, Karnataka, India. Roots (Figure 1A) were air dried at $40-50{ }^{\circ} \mathrm{C}$ in a hot air oven for 6-7 $\mathrm{h}$ and reduced to coarse powder (Figure 1B) by using a grinder and kept in a well closed air tight container for further use. The root extracts were prepared by using $50 \mathrm{~g}$ of powdered root in $100 \mathrm{~mL}$ chloroform, $\mathrm{n}$ butanol, and ethyl acetate using a soxhlet apparatus, and the temperature was maintained at $60^{\circ} \mathrm{C}$ for $6 \mathrm{~h}$, and with water using the hot extraction method at $80^{\circ} \mathrm{C}$ for $6 \mathrm{~h}$. After removing the biomass residues by filtration, pooled extracts were concentrated on a rotary vacuum evaporator and further dried using an oven at $60^{\circ} \mathrm{C}$, except for the water extract, and each obtained extract was stored in a tightly closed bottle for further use [25].

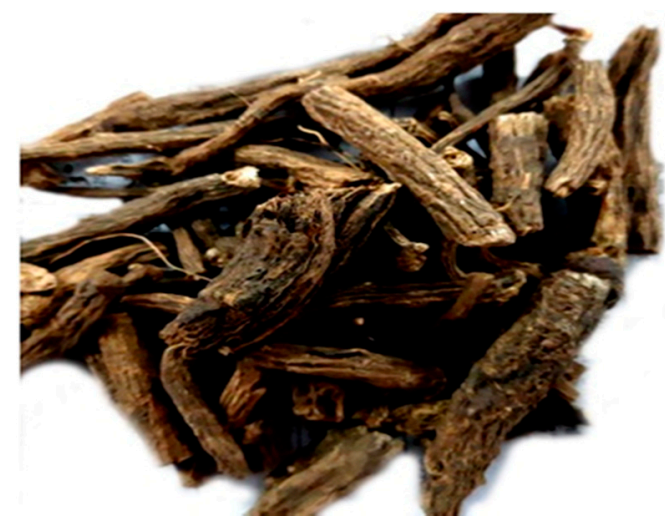

(A)

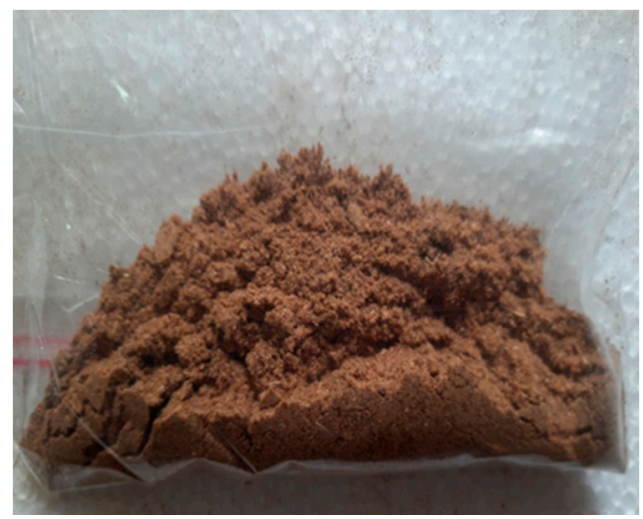

(B)

Figure 1. Images of (A) Saussurea lappa root and (B) coarse powder.

\subsection{Phyto-Chemical Analysis}

The aqueous, chloroform, n-butanol, and ethyl acetate solvents were investigated for the presence of various phyto-constituents. Each stock solution was prepared by dissolving $10 \mathrm{mg}$ of powder in $100 \mathrm{~mL}$ of the respective solvents, subjected to solvent extraction, and kept in a rotary shaker at $120 \mathrm{rpm}$ for $48 \mathrm{~h}$. Then extracts were air dried and stored for further usage. The crude extracts were re-suspended in their respective solvents, and qualitative tests were carried out for the alkaloids, flavonoids, carbohydrates, glycosides, tannins, proteins, resins, steroids, and triterpenoids as per standard protocols [26,27].

\subsection{GC-MS Analysis of S. lappa Root Extracts}

The qualitative analyses of $S$. lappa chloroform, n-butanol, and ethyl acetate root extracts were carried out by GC-MS analysis using a Perkin Elmer instrument (GCMS- 
QP2010 SE, Shimadzu Instrument, Columbia, MD, USA). The prepared root extracts of chloroform, n-butanol, and ethyl acetate were each added with $100 \mu \mathrm{L}$ of derivatization reagent $\left(80 \mu \mathrm{L}\right.$ BFSTA $+20 \mu \mathrm{L}$ TMCS) and incubated at $65{ }^{\circ} \mathrm{C}$ for $1 \mathrm{~h}$. Then each extract was injected in a Rtx5MS-30 m column with $0.25-\mathrm{mm}$ ID and $0.25 \mu \mathrm{m}$ df. The temperature maintained for injection was $300{ }^{\circ} \mathrm{C}$, with an interface temperature at $300{ }^{\circ} \mathrm{C}$, and an iron source maintained at $250{ }^{\circ} \mathrm{C}$. Helium gas was used as the carrier gas at a flow rate of $1 \mathrm{~mL} \mathrm{~min}^{-1}$. The analysis was performed by isothermal heating for $1 \mathrm{~min}$ at $100{ }^{\circ} \mathrm{C}$ followed by heating at $300{ }^{\circ} \mathrm{C}$ for $20 \mathrm{~min}$. The mass spectra were recorded at $2 \mathrm{scan} \mathrm{sec}^{-1}$ with a scanning range of 40 to $850 \mathrm{~m} / \mathrm{z}$. Components were quantified based on peak areas and normalization based on the internal standard using Turbo mass software [28]. The best appropriate and promising GC-MS results displaying maximum numbers of compounds were found in the n-butanol fraction. It was therefore selected for further anti-oxidant and anti-cancer studies against the hepato-cellular cell line, HepG2, considering that research of n-butanol S. lappa root extract on HCC and its mechanism of anticancer activity are scarce. Additionally, qualitative estimation of the active constituent has yet to be demonstrated.

\subsection{Anti-Oxidant Assays}

\subsubsection{DPPH (2,2-diphenyl-1-picrylhydrazyl) Free Radical Scavenging Assay}

The antiradical assays of $S$. lappa n-butanol root extract were measured by DPPH free radical scavenging assay. In brief, $3 \mathrm{~mL}$ of DPPH solution (\#RM2798-1G, DPPH, Himedia, Mumbai, India) $(0.003 \%$ DPPH in methanol) was mixed with $1 \mathrm{~mL}$ of different concentrations $(20,40,60,80$, and $100 \mu \mathrm{g} / \mathrm{mL})$ of extract and ascorbic acid as separate standards. The tubes were kept in the dark for $30 \mathrm{~min}$ at room temperature and then measured for optical density at $517 \mathrm{~nm}$ using a UV-Vis spectrophotometer. The absorbance of standard and control was also noted, while ascorbic acid was used as standard reference. The DPPH radical scavenging assay was calculated by using the following formula:

$$
\text { Scavenging activity }(\%)=\left(\mathrm{A}_{0}-\mathrm{A}_{1}\right) / \mathrm{A}_{0} \times 100
$$

where $\mathrm{A}_{0}=$ Absorbance of DPPH and $\mathrm{A}_{1}=$ Absorbance of the sample.

\subsubsection{Ferrous Reducing Antioxidant Capacity Assay (FRAC)}

The method is based on the reducing power of $S$. lappa root extract. First, $2 \mathrm{~mL}$ of extract was mixed with $2 \mathrm{~mL}$ of $2 \mathrm{M}$ sodium phosphate buffer $(\mathrm{pH} 6.6)$ and $3 \mathrm{~mL}$ of $1 \%$ potassium ferricyanide. Then, the mixture was incubated at $50{ }^{\circ} \mathrm{C}$ for $20 \mathrm{~min}$. Next, $3 \mathrm{~mL}$ of $10 \%$ trichloroacetic acid (TCA) was added to mixture and then centrifuged at $4500 \mathrm{rpm}$ for $10 \mathrm{~min}$. The supernatant solution $(3 \mathrm{~mL})$ was mixed with distilled water $(3 \mathrm{~mL})$ and ferric chloride (1 mL) to measure absorbance at $700 \mathrm{~nm}$ [29].

\subsection{Anticancer Activity Assessment of S. lappa Root Extract}

\subsubsection{Cell Culture}

The HepG2-Human hepatocellular adenocarcinoma cancer cell lines were obtained from NCCS Pune, India. Cell lines were cultured in DMEM (Dulbecco's modified Eagle's medium) low glucose medium (\#AL149, Himedia, Mumbai, Indai) supplemented with $10 \%$ fetal bovine serum (FBS), penicillin (100 IU $/ \mathrm{mL})$, streptomycin $(100 \mu \mathrm{g} / \mathrm{mL})$, and amphotericin-B $(5 \mu \mathrm{g} / \mathrm{mL})$ in a humidified incubator of $5 \% \mathrm{CO}_{2}$ at $37^{\circ} \mathrm{C}$ till confluence was produced. These cell lines in the exponential growth period were washed, dissociated with trypsin $(0.2 \%)$, and resuspended in complete culture media.

\subsubsection{In Vitro Cytotoxic Assay (MTT Assay) Method}

A $200 \mu \mathrm{L}$ cell suspension was taken in 96 well plates at the required cell density (20,000 cells per well) and incubated at $37{ }^{\circ} \mathrm{C}$ and $5 \% \mathrm{CO}_{2}$ for $24 \mathrm{~h}$, during which a partial monolayer formed. Then, cells were treated with n-butanol root extract of different concentration $(12.5 \mu \mathrm{g} / \mathrm{mL}, 25 \mu \mathrm{g} / \mathrm{mL}, 50 \mu \mathrm{g} / \mathrm{mL}, 100 \mu \mathrm{g} / \mathrm{mL}$, and $200 \mu \mathrm{g} / \mathrm{mL})$, while control wells, which were untreated cells, received only maintenance medium, and positive 
control received camptothecin (\#C9911, SigmaAldrich, St. Louis, MO, USA). The plates were incubated at $37^{\circ} \mathrm{C}$ in a humidified atmosphere with $5 \% \mathrm{CO}_{2}, 75 \%$ relative humidity for $24 \mathrm{~h}$ (Healforce, China). Then, $50 \mu \mathrm{L}$ of MTT labeling compound was added, followed by incubation for $4 \mathrm{~h}$. Then $100 \mu \mathrm{L}$ of DMSO was added to each well to dissolve the formazan format on the last step. Using a microplate (ELISA) reader (ELX-800, BioTek, Vadodara, India) at wavelength $570 \mathrm{~nm}$, the absorbance of the samples was measured and the IC50 value is calculated by using a linear regression equation, i.e., $\mathrm{Y}=\mathrm{Mx}+\mathrm{C}$, where $Y=50$, and $M$ and $C$ values were derived from the viability graph. Three independent experiments were performed.

The influence of the extract of S. lappa on the viability was determined using the following formula:

$\%$ viability $=($ A570 of treated cells - A570 of blank cells $) /($ A570 of controlled cells - A570 of blank cells $) \times 100$.

The formula for calculation of the percentage of cytotoxicity [30]:

$$
\% \text { cytotoxicity }=100-\% \text { cell viability. }
$$

\subsection{Apoptosis Assessment with Acridine Orange-Ethidium Bromide Staining}

The n-butanol root extract of $S$. lappa was directed to check the rate of cell death in the HepG2 cancer cell line. The stains used to conduct nuclear morphological changes were acridine orange (AO) and ethidium bromide (EB). The HepG2-human hepatocellular adenocarcinoma cancer cell lines were obtained from NCCS Pune. The cultured cells were taken in a 12-well plate above the sterile coverslips coated with poly L-ornithine solution at a density of $2 \times 105$ cells $/ 2 \mathrm{~mL}$ and incubated in a $\mathrm{CO}_{2}$ incubator overnight at $37^{\circ} \mathrm{C}$ for $24 \mathrm{~h}$. Then $56.76 \mu \mathrm{g} / \mathrm{mL}$ of the root extract was treated to the culture medium for $24 \mathrm{~h}$ and not the untreated well. After incubation, the plates were washed with PBS buffer and the PBS was removed; then the coverslip was removed and the cell plate was washed with $1 \mathrm{~mL} 1$ X DPBS. The cells were stained with $200 \mu \mathrm{L}$ staining solution for $10 \mathrm{~min}$ and observed under fluorescence microscope with a filter cube with excitation of 560/40 nm and emission of $645 / 75 \mathrm{~nm}$ for $\mathrm{EtBr}$ and excitation of 470/40 and emission of 525/50 for acridine orange [31]. The images were taken from Image J Software v1.48.

\subsection{Cytochrome C Releasing Apoptosis Assay}

The cytochrome $\mathrm{C}$ releasing apoptosis assay provides an effective means for detecting cytochrome $\mathrm{C}$ translocation from mitochondria into the cytosol during apoptosis [32]. The n-butanol root extract of $S$. lappa was directed to check the cytochrome $C$ releasing apoptosis assay in our target cell line. The cultured cells were taken in a 6-well plate at a density of $3 \times 105$ cells $/ 2 \mathrm{~mL}$ and incubated in $\mathrm{CO}_{2}$ incubator overnight at $37^{\circ} \mathrm{C}$ for $24 \mathrm{~h}$. Then, $56.76 \mu \mathrm{g} / \mathrm{mL}$ of the root extract was treated to the culture medium and not the untreated well, followed by incubation for $24 \mathrm{~h}$. At the end of the treatment, the cells were harvested directly into $12 \times 75 \mathrm{~mm}$ polystyrene tubes. The cells were centrifuged for five minutes at $300 \times g$ at $25^{\circ} \mathrm{C}$, and then the supernatant was removed carefully. The cells were fixed and permeabilized in $70 \%$ pre-chilled absolute ethanol and stored in $-20{ }^{\circ} \mathrm{C}$ for 30-40 min. The suspension was centrifuged again at $300 \times g$ at $25^{\circ} \mathrm{C}$, and ethanol was removed. The cells were washed twice with PBS to remove excess ethanol, and the PBS was decanted completely. The cells were stained with $10 \mu \mathrm{L}$ of cytochrome C-conjugated FITC antibody (Invitrogen) for $20 \mathrm{~min}$ in the dark at RT. The cells were re-suspended in $200 \mu \mathrm{L}$ of PBS and analyzed by flow cytometry using the FL-1 channel at excitation of 488 $\mathrm{nm}$ and emission wavelength of $520 \mathrm{~nm}$, respectively, to analyze cellular distributions of cytochrome C [32].

\subsection{Gene Quantification by $q R T-P C R$}

Total RNA was isolated using a Qiagen RNeasy kit for all samples. It was treated with DNAse and purified to avoid genomic DNA contamination. RNA was quantified 
by UV-Vis using QIAxpert (Qiagen, Foster City, CA, USA). RNA was also run on agarose gel. The ladder used was Lambda HindIII/EcoRI. Total extracted RNA $(1 \mu \mathrm{g})$ was reverse transcribed using an IScript cDNA synthesis kit (Bio-Rad, Foster City, CA, USA) with random hexamer + oligo dT primers as per the reaction mentioned in Table 1 . The tubes were incubated in a PCR cycler with priming for $5 \mathrm{~min}$ at 25 degrees, RT $20 \mathrm{~min}$ at 46 degrees, RT inactivation $1 \mathrm{~min}$ at 95 degrees. The newly synthesized first strand cDNA was stored at $-20^{\circ} \mathrm{C}$. The primers designed for the respective gene expression studies were as mentioned in Table 2 below. All the primers (HPLC grade) were synthesized from Eurofins, Bangalore. The relative quantification of the gene expression was done in Qiagen Rotor Gene Q 5plex HRM using the SYBR Green Chemistry (SensiFAST SYBR Hi-ROX kit, Bioline, Taunton, MA, USA). The reaction was carried out in a $25 \mu \mathrm{L}$ reaction volume with the components as first strand cDNA-1 $\mu \mathrm{L}$, SYBR Green Master Mix (2X) $12.5 \mu \mathrm{L}$, forward primer $(10 \mu \mathrm{M})-1 \mu \mathrm{L}$, reverse primer $(10 \mu \mathrm{M})-1 \mu \mathrm{L}$, and nuclease-free water-9.5 $\mu \mathrm{L}$. The thermo-cycling conditions with a total number of 40 cycles were established as $5 \mathrm{~min}$ at $95^{\circ} \mathrm{C}$, followed by $10 \mathrm{~s}$ at $95^{\circ} \mathrm{C}, 20 \mathrm{~s}$ at $60^{\circ} \mathrm{C}$, and $20 \mathrm{~s}$ at $72{ }^{\circ} \mathrm{C}$. Each reaction was conducted in triplicate, and the $2^{-\Delta \Delta C t}$ method was applied to calculate fold-change differences between control and treated samples, and GAPDH was used as an internal control.

Table 1. cDNA synthesis reaction mix.

\begin{tabular}{cc}
\hline cDNA Synthesis Reaction Mix Constituents & Vol in $\mu \mathrm{L}$ \\
\hline 5X IScript reaction mix & 10 \\
\hline Nuclease free water & 18 \\
\hline RNA & 10 \\
\hline Reverse transcriptase enzyme & 2 \\
\hline
\end{tabular}

Table 2. Primer sequences for quantitative real-time polymerase chain reaction (qRT-PCR).

\begin{tabular}{|c|c|c|c|}
\hline & Gene Name & Forward Primer Sequences & Reverse Primer Sequences \\
\hline 1 & Caspase 3 (210 bp) & 5'-TGTTTGTGTGCTTCTGAGCC-3' & 5'-CACGCCATGTCATCATCAAC-3' \\
\hline 2 & Bcl-2 (141 bp) & 5'-ATGTGTGTGGAGACCGTCAA-3' & 5'-GCCGTACAGTTCCACAAAGG-3' \\
\hline 3 & Bax (133 bp) & 5'-ATGTTTTCTGACGGCAACTTC-3' & 5'-AGTCCAATGTCCAGCCCAT-3' \\
\hline 4 & GAPDH (113 bp) & 5'-TCAAGAAGGTGGTGAAGCAG-3' & $5^{\prime}$-AAAGGTGGAGGAGTGGGTGT-3' \\
\hline
\end{tabular}

\subsection{Statistical Analysis}

The results of each experiment were expressed as the means \pm standard deviation (SD, for each group $n=3$ ). Statistical significance at $p<0.05$ between the groups was evaluated by one-way ANOVA analysis of variance.

\section{Results}

\subsection{Phytochemical Analysis}

The results of phytochemical tests confirmed that its roots are rich source of various bioactive compounds such as flavonoids, alkaloids, glycosides, coumarines, phenols and tannins, steroids, and essential oil contents. The presence of various phytochemicals was noticed qualitatively in all the four different extracts, and the maximum number of phytochemicals was identified in aqueous extracts (Table 3). 
Table 3. Phytochemical investigation of S. lappa root extracts.

\begin{tabular}{|c|c|c|c|c|}
\hline $\begin{array}{l}\text { Chemical } \\
\text { Constituent }\end{array}$ & $\begin{array}{l}\text { Aqueous } \\
\text { Extract }\end{array}$ & $\begin{array}{c}\text { Chloroform } \\
\text { Extract }\end{array}$ & $\begin{array}{c}\text { n-Butanol } \\
\text { Extract }\end{array}$ & $\begin{array}{c}\text { Ethyl Acetate } \\
\text { Extract }\end{array}$ \\
\hline Alkaloids & + & + & + & + \\
\hline Steroids & + & + & + & - \\
\hline Terpenoids & + & + & + & - \\
\hline Flavonoids & + & + & + & + \\
\hline Carbohydrates & + & + & + & + \\
\hline Proteins & + & - & + & + \\
\hline Phenols & + & + & + & + \\
\hline Tannins & + & + & + & + \\
\hline Saponins & + & + & - & - \\
\hline Glycosides & + & + & + & + \\
\hline Coumarins & + & - & + & + \\
\hline Fixed oil & + & - & + & - \\
\hline
\end{tabular}

(+) Indicates the presence and (-) indicates absence.

\subsection{Identification of S. Lappa Root Components by GC-MS Analysis}

Figure 2 depicts the GC-MS analysis of $S$. lappa root extracts of n-butanol root extract of Saussurea lappa. Its chloroform, n-butanol, and ethyl acetate extracts recorded 54 compounds, among those costunolide, Bohlmann k2631, and 2(3H)-benzofuranone,6-ethenylhexahydro6-methyl-3-methylene-7-(1-methylethenyl)-, 3S-( $3 \alpha, 3 \mathrm{a} \alpha, 6 \alpha, 7 \beta, 7 \mathrm{a} \beta)]$-were present in both n-butanol and ethyl acetate extract; and 1,2-dicaprin was present in chloroform and nbutanol extract. Among the 54 compounds, the maximum (27) were seen in n-butanol extract. It was therefore selected for further anti-oxidant and anti-cancer studies. The retention time and the percentage amounts of the compositions with their molecular formula present in n-butanol root extract are displayed in (Table 4), and the chemical structures of the major constituents are displayed in Figure 3.<smiles>CCCCCCCCCC(=O)OCC(O)COC(=O)CCCCCCCCC</smiles>

\section{1,3-Dicaprin}<smiles>CCCCCCCCC(O)C(C)CCCCCCCC(=O)OC</smiles>

Octadecanoic acid,9,10-dihydroxy-methyl ester

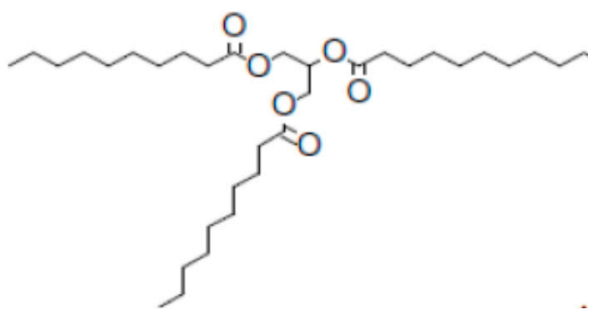

Decanoic acid,1,2,3-propanetriyl ester

Figure 2. Major constituents found in n-butanol S. lappa root extract. 
Table 4. Compounds present in n-butanol root extract of Saussurea lappa analyzed by GC-MS.

\begin{tabular}{|c|c|c|c|c|}
\hline S1 No & Retention Time & Peak Area \% & Name of the Compound & Molecular Formula \\
\hline 1 & 4.289 & 2.8 & Dimethylsulfoxonium formylmethylide & $\mathrm{C}_{4} \mathrm{H}_{8} \mathrm{O}_{2} \mathrm{~S}$ \\
\hline 2 & 5.904 & 0.6 & (Z)-1-Chloro-2(methylsulfonyl)ethylene & $\mathrm{C}_{3} \mathrm{H}_{5} \mathrm{ClO}_{2} \mathrm{~S}$ \\
\hline 3 & 9.046 & 3.4 & cis,cis,cis-7,10,13-Hexadecatrienal & $\mathrm{C}_{16} \mathrm{H}_{26} \mathrm{O}$ \\
\hline 4 & 10.321 & 0.1 & 1-Gala-1-ido-octose & $\mathrm{C}_{8} \mathrm{H}_{16} \mathrm{O}_{8}$ \\
\hline 5 & 10.866 & 0.9 & $\begin{array}{l}\text { 2(3H)-Benzofuranone,6-ethenylhexahydro-6-methyl-3- } \\
\text { methylene-7-(1-methylethenyl)-, } \\
\text { [3aS-(3a } \alpha, 6 \alpha, 7 \beta, 7 \mathbf{a} \beta)]-\end{array}$ & $\mathrm{C}_{15} \mathrm{H}_{20} \mathrm{O}_{2}$ \\
\hline 6 & 11.111 & 2.6 & Tricyclo $[4.3 .1 .1(3,8)]$ undecane-1-carboxylic acid & $\mathrm{C}_{12} \mathrm{H}_{18} \mathrm{O}_{2}$ \\
\hline 7 & 11.667 & 0.6 & Bohlmann k2631 & $\mathrm{C}_{15} \mathrm{H}_{20} \mathrm{O}_{2}$ \\
\hline 8 & 12.072 & 0.7 & Costunolide & $\mathrm{C}_{15} \mathrm{H}_{20} \mathrm{O}_{2}$ \\
\hline 9 & 12.312 & 0.5 & $\begin{array}{l}\text { 2(3H)-Benzofuranone,6-ethenylhexahydro-6-methyl-3- } \\
\text { methylene-7-(1-methylethenyl)-, } \\
\text { [3aS-(3a } \alpha, 6 \alpha, 7 \beta, 7 \mathbf{a} \beta)]-\end{array}$ & $\mathrm{C}_{15} \mathrm{H}_{20} \mathrm{O}_{2}$ \\
\hline 10 & 12.502 & 11.5 & Octadecanoic acid,9,10-dihydroxy-,methyl ester & $\mathrm{C}_{19} \mathrm{H}_{38} \mathrm{O}_{4}$ \\
\hline 11 & 14.408 & 3.7 & 1,2-Dicaprin & $\mathrm{C}_{23} \mathrm{H}_{44} \mathrm{O}_{4}$ \\
\hline 12 & 15.088 & 9.4 & Decanoic acid,1,2,3-propanetriyl ester & $\mathrm{C}_{33} \mathrm{H}_{62} \mathrm{O}_{6}$ \\
\hline 13 & 15.433 & 1.1 & Vinyl decanoate & $\mathrm{C}_{12} \mathrm{H}_{22} \mathrm{O}_{2}$ \\
\hline 14 & 15.588 & 6.8 & Decanoic anhydride & $\mathrm{C}_{20} \mathrm{H}_{38} \mathrm{O}_{3}$ \\
\hline 15 & 15.688 & 4.8 & Decanoic acid, 2-hydroxy-1-(hydroxymethyl)ethyl ester & $\mathrm{C}_{13} \mathrm{H}_{26} \mathrm{O}_{4}$ \\
\hline 16 & 17.234 & 8.8 & $\begin{array}{c}\text { 3,5,9-Trioxa-4-phosphanonadecan-1-aminium, 4- } \\
\text { hydroxy-N,N,N-trimethyl-10-oxo-7-[(1-oxodecyl)oxy]-, } \\
\text { hydroxide, innersalt, 4- }\end{array}$ & $\mathrm{C}_{28} \mathrm{H}_{56} \mathrm{NO}_{8} \mathrm{P}$ \\
\hline 17 & 17.469 & 17.3 & 1,3-Dicaprin & $\mathrm{C}_{23} \mathrm{H}_{44} \mathrm{O}_{5}$ \\
\hline 18 & 17.714 & 2.9 & Estra-1,3,5(10)-trien-17'-ol & $\mathrm{C}_{18} \mathrm{H}_{24} \mathrm{O}$ \\
\hline 19 & 18.259 & 0.6 & $\begin{array}{l}\text { 9,10-Secocholesta-5,7,10(19)-triene-3,24,25-triol, } \\
(3 \%, 5 Z, 7 \mathrm{E}) \text { - }\end{array}$ & $\mathrm{C}_{27} \mathrm{H}_{44} \mathrm{O}_{3}$ \\
\hline 20 & 18.535 & 2.2 & 2-Bromotetradecanoic acid & $\mathrm{C}_{14} \mathrm{H}_{27} \mathrm{BrO}_{2}$ \\
\hline 21 & 18.860 & 1.7 & Cyclopropanetetradecanoic acid, 2-octyl-, methyl ester & $\mathrm{C}_{26} \mathrm{H}_{50} \mathrm{O}_{2}$ \\
\hline 22 & 19.385 & 2.0 & 1-Heptatriacotanol & $\mathrm{C}_{37} \mathrm{H}_{76} \mathrm{O}$ \\
\hline 23 & 19.870 & 0.3 & Digitoxin & $\mathrm{C}_{41} \mathrm{H}_{64} \mathrm{O}_{13}$ \\
\hline 24 & 20.550 & 0.1 & Oleic Acid & $\mathrm{C}_{18} \mathrm{H}_{34} \mathrm{O}_{2}$ \\
\hline 25 & 21.021 & 0.2 & 1,25-Dihydroxyvitamin D3, TMS derivative & $\mathrm{C}_{30} \mathrm{H}_{52} \mathrm{O}_{3} \mathrm{Si}$ \\
\hline 26 & 21.386 & 0.3 & Cucurbitacin b, 25-desacetoxy- & $\mathrm{C}_{30} \mathrm{H}_{44} \mathrm{O}_{6}$ \\
\hline 27 & 21.681 & 1.0 & 2-Myristynoyl pantetheine & $\mathrm{C}_{25} \mathrm{H}_{44} \mathrm{~N}_{2} \mathrm{O}_{5} \mathrm{~S}$ \\
\hline
\end{tabular}




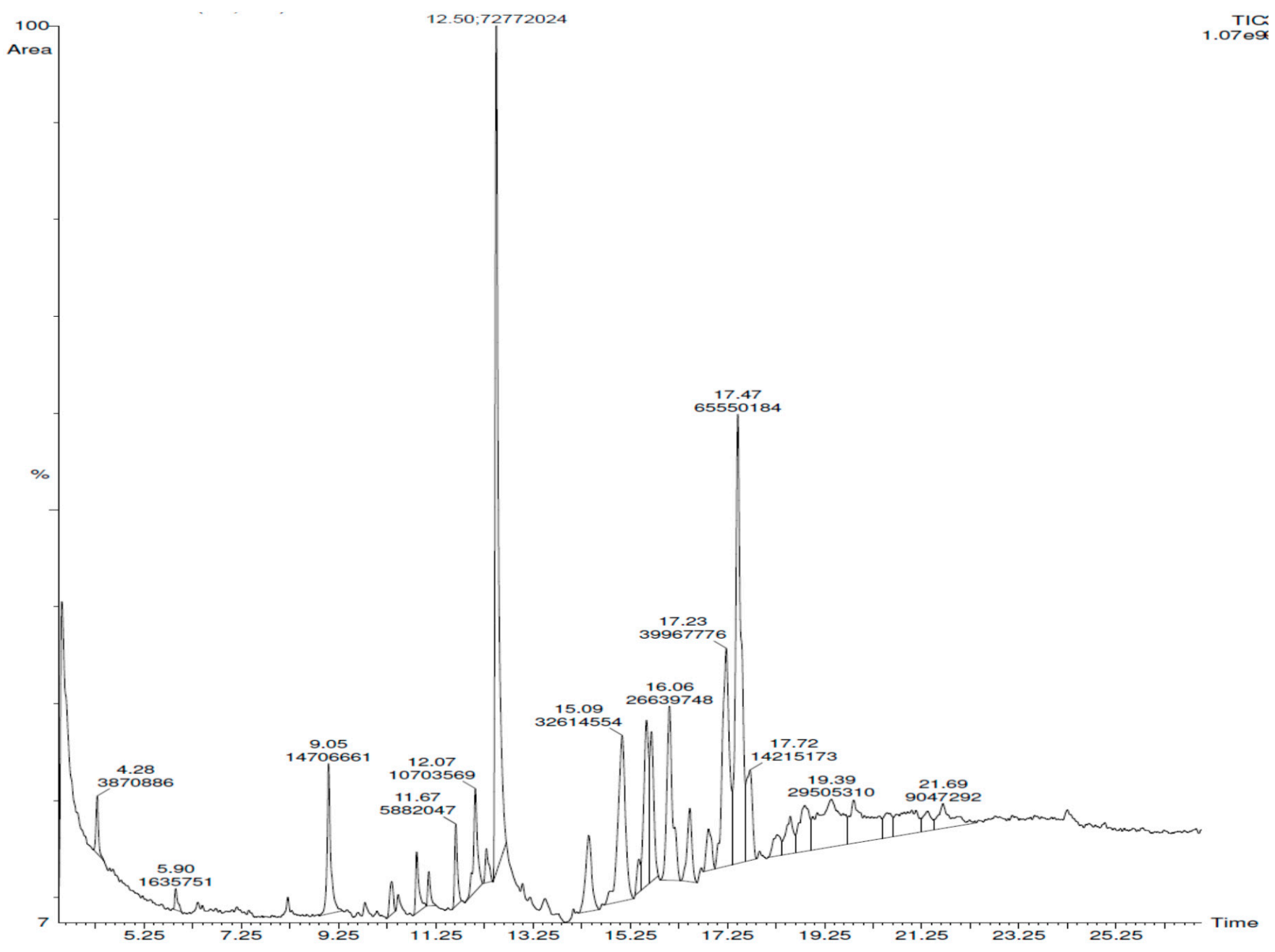

Figure 3. Chromatogram of n-butanol root extract of Saussurea lappa by GC-MS.

\subsection{Antioxidant Assays}

The values of the radical scavenging effect of Saussurea lappa n-butanol root extract and ascorbic acid are depicted in Figure 4A, where both exhibited dose dependent increased scavenging free radicals of DPPH where it converted to DPPHH, with increasing concentrations. The scavenging activity of extract was greater than $50 \%$ at concentrations of $100 \mu \mathrm{g} / \mathrm{mL}$ but less than that of standard ascorbic acid. In FRAC, reducing power of extract was determined by reduction of $\mathrm{Fe}^{+3}$ to $\mathrm{Fe}^{+2}$ in various concentrations of extract. The absorbance of mixture was increased with the increase in concentration of extract, indicating the reducing potential of root extract (Figure 4B). 


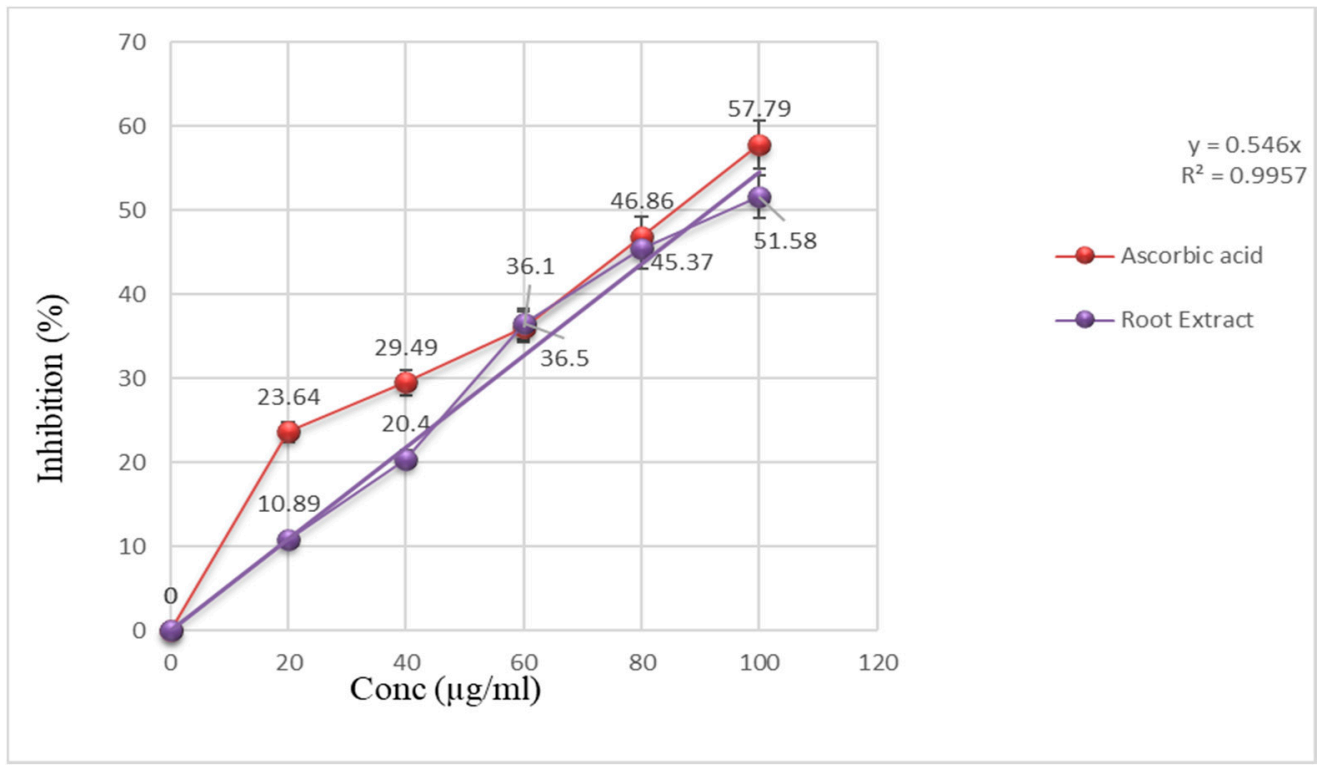

(A)

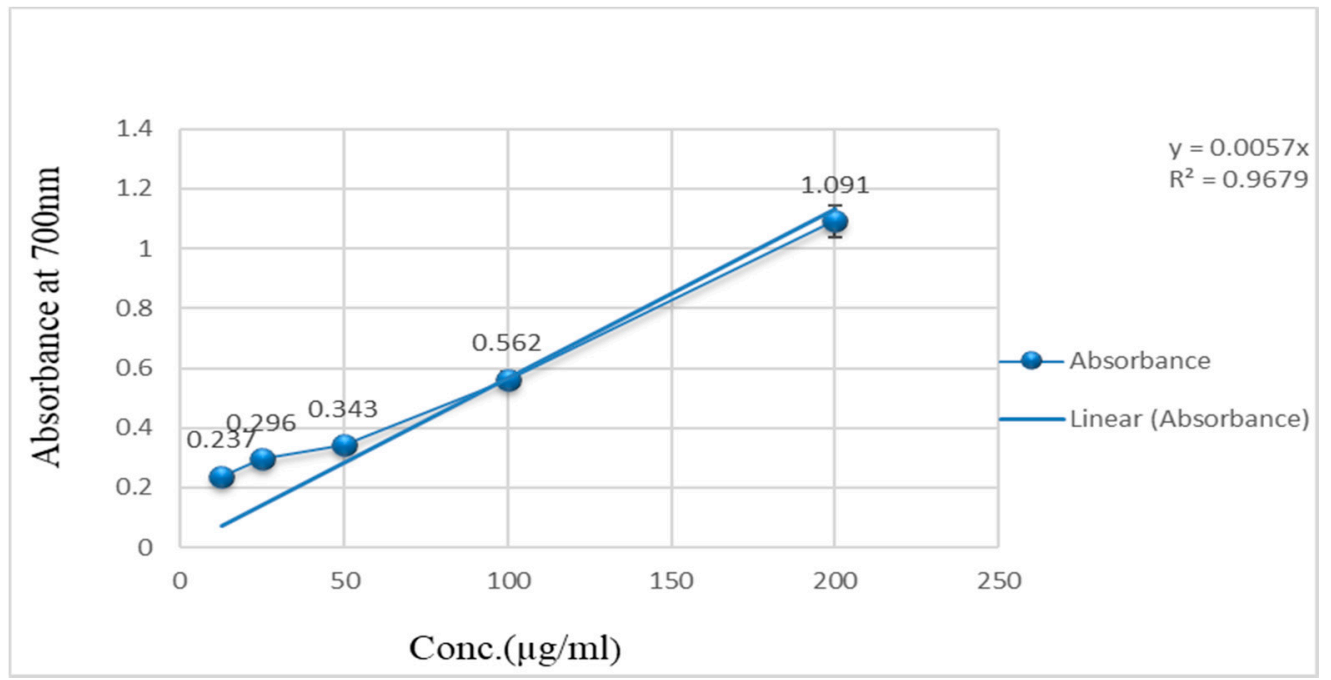

(B)

Figure 4. (A) Free radical scavenging activity of the n-butanol extracts from roots of S. lappa and positive controls measured in DPPH assay. (B) Absorbance of FRAC assay of root extract at different concentrations.

\subsection{Anticancer Activity of S. lappa N-Butanol Root Extract}

The n-butanol root extract of $S$. lappa was treated against HepG2 cell lines for anticancer activity by MTT assay. The extract showed significant growth inhibitory potential with the IC50 value at a concentration of $56.76 \mu \mathrm{g} / \mathrm{mL}$ compared to the positive control, camptothecin, with an IC50 concentration at $10 \mu \mathrm{M}$ equivalent to $3.48 \mu \mathrm{g} / \mathrm{mL}$ used for the study, after the treatment for $24 \mathrm{~h}$ of incubation at $37^{\circ} \mathrm{C}$ temperature (Figures 5 and 6). Thus, n-butanol root extract showed $61.36 \%$ similar potency against the HepG2 cancer cells compared to camptothecin. 


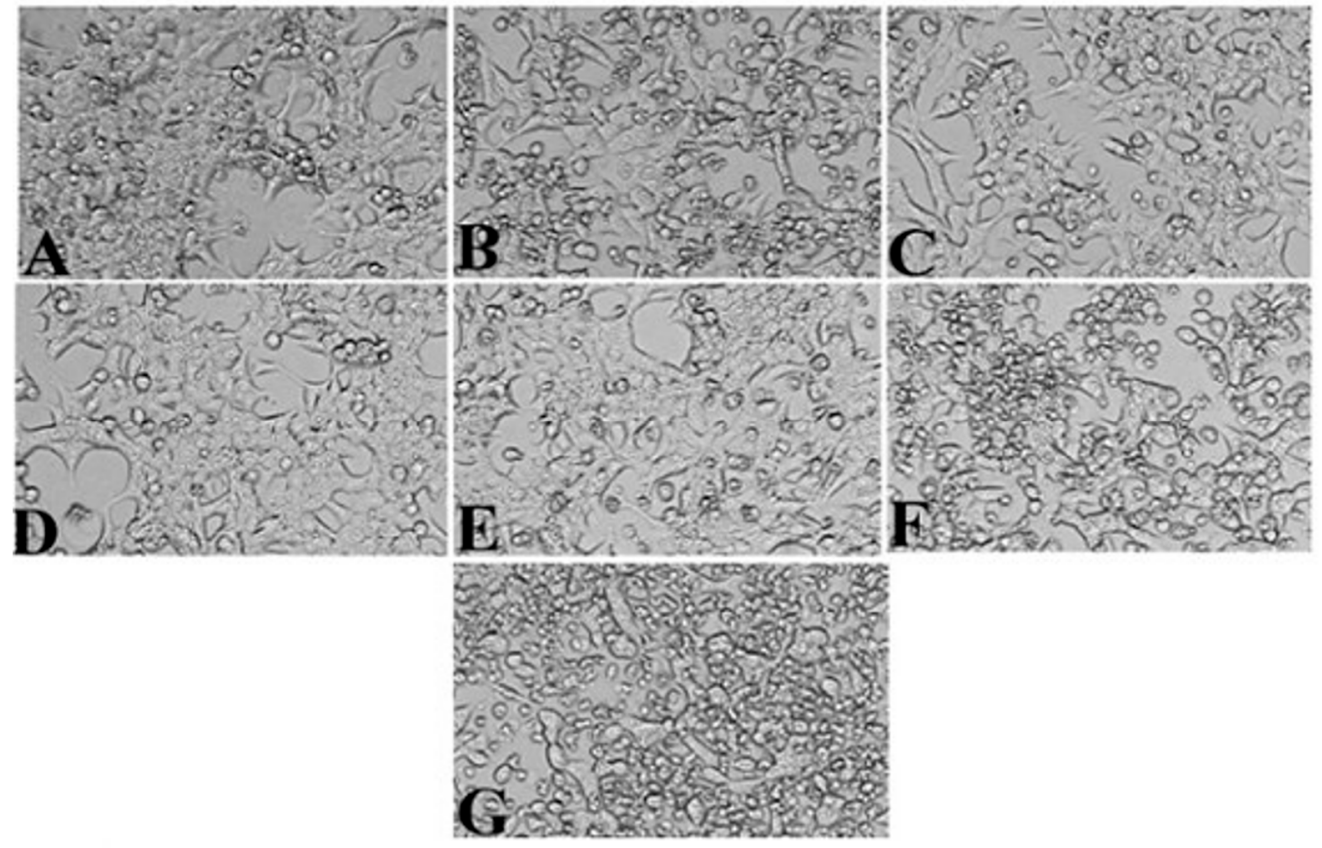

Figure 5. In vitro anticancer activity of root extract of Saussurea lappa ((A) - untreated, (B) - positive control, (C) $-12.5 \mu \mathrm{g} / \mathrm{mL},(\mathbf{D})-25 \mu \mathrm{g} / \mathrm{mL},(\mathbf{E})-50 \mu \mathrm{g} / \mathrm{mL},(\mathbf{F})-100 \mu \mathrm{g} / \mathrm{mL},(\mathbf{G})-200 \mu \mathrm{g} / \mathrm{mL})$. (the images were captured at $10 \times$ magnification by inverted biological microscope).

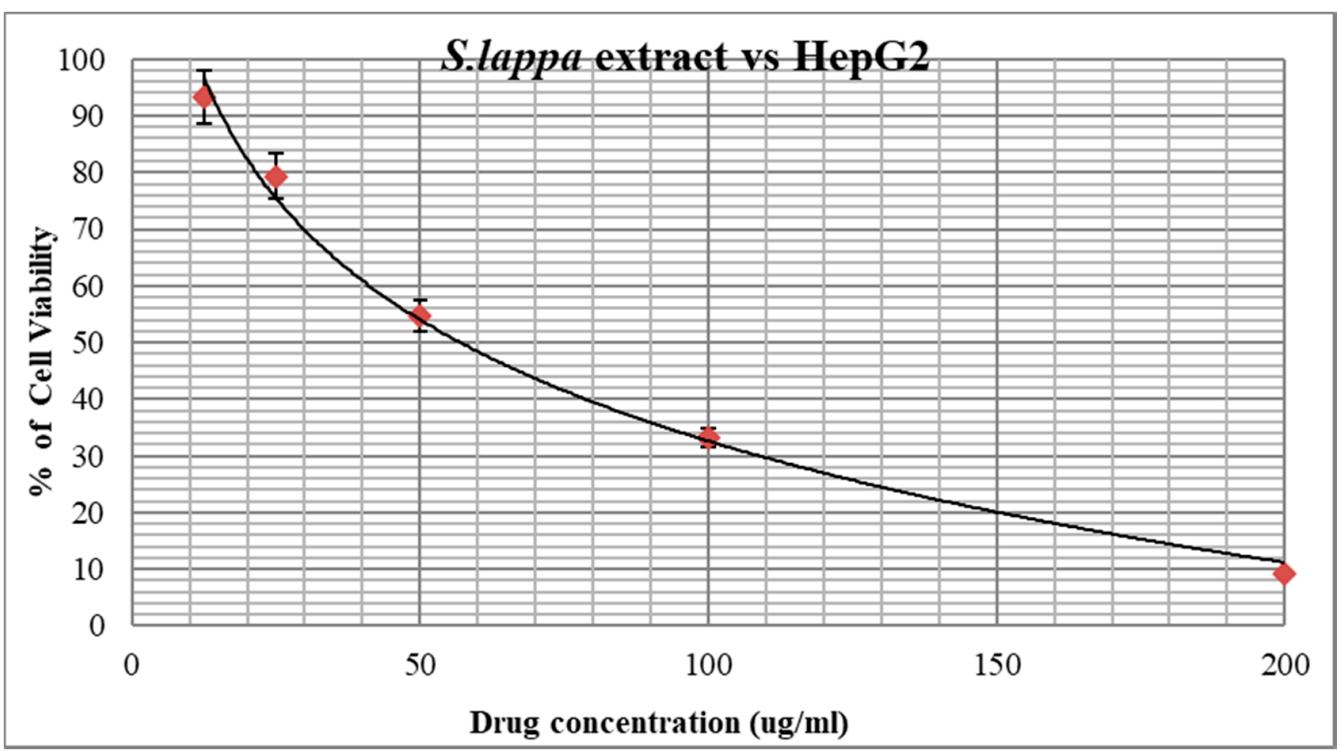

Figure 6. Graph showing the percentage cell viability of root extract against HepG2 cell line after $24 \mathrm{~h}$.

3.5. Apoptosis Assessment with Acridine Orange-Ethidium Bromide Double Staining Assay of S. lappa N-Butanol Root Extract

Apoptotic cell morphological analysis was carried out on untreated and S. lappa nbutanol root extract-treated HepG2-human hepatocellular adenocarcinoma cancer cells using the acridine orange $(\mathrm{AO})$ and ethidium bromide $(\mathrm{EB})$ double staining method. These are nucleic acid-binding dyes used for fluorescence of cancer cells. AO is an intercalating dye that gives a green color, which indicates the viable cells, whereas the EB produces a red color, indicating the dead cells (Figure 7). After the treatment of root extract against HepG2 cancer cells, the cells were observed under a fluorescent microscope. The S. lappa n-butanol extract concentration of $56.76 \mu \mathrm{g} / \mathrm{mL}$ produced nuclear features suggestive of apoptosis. 


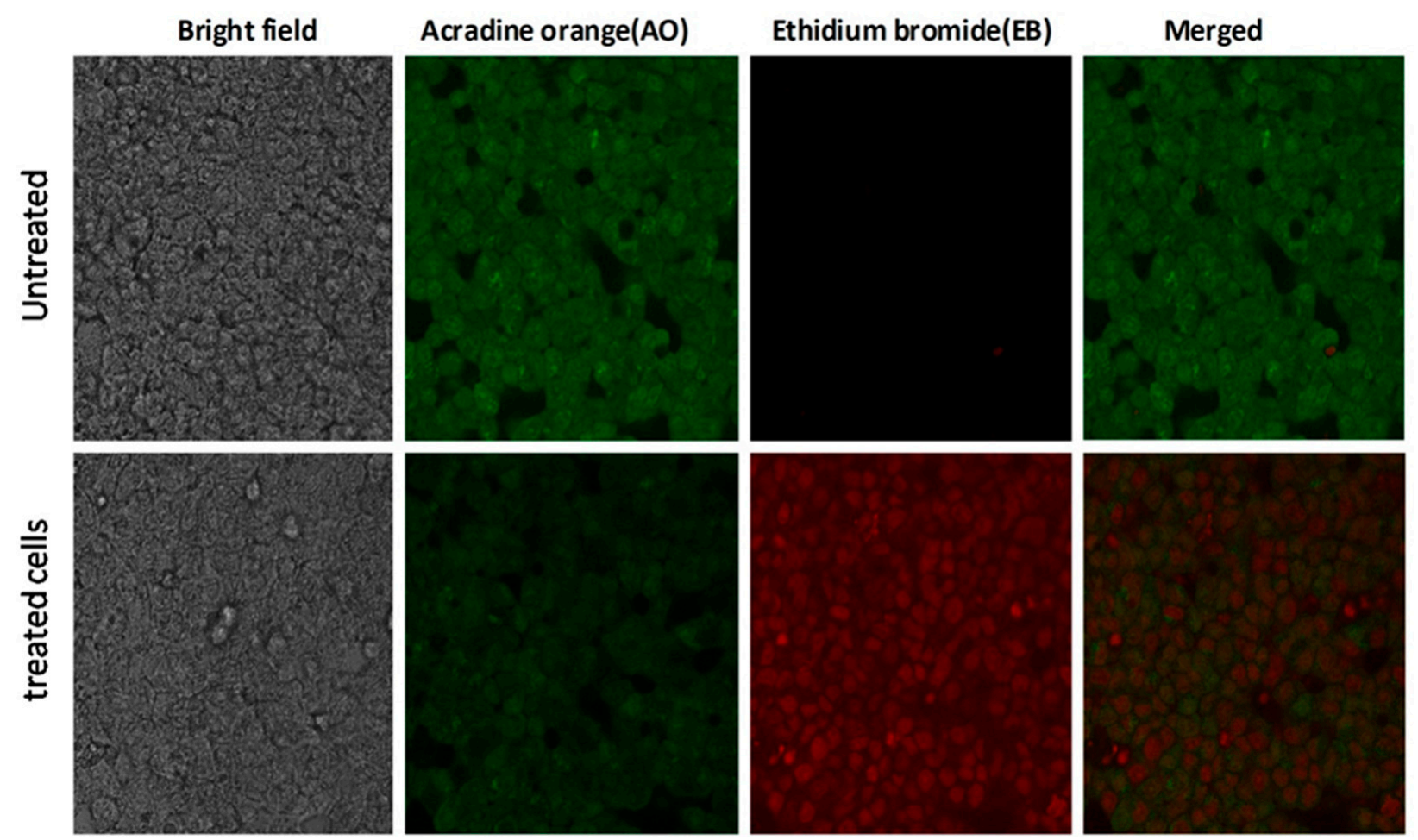

Figure 7. S. lappa n-butanol root extract-induced apoptosis. Dual staining study of HepG2 cells by acridine orange (AO) and ethidium bromide (EB) (AO represents viable cells and EB represents dead cells). Untreated and treated with n-butanol extract $(56.76 \mu \mathrm{g} / \mathrm{mL})$ representing the changes in nuclear morphology of cells (the images were captured at $40 \times$ magnification).

\subsection{Cytochrome C Releasing Apoptosis Assay}

We observed that in HepG-2 cells, the expression of cytochrome $C$ was very low in untreated cells $(0.64 \%)$ compared to camptothecin $(10 \mu \mathrm{m})$, showing $82.89 \%$ cytochrome C expression. The $S$. lappa extract with IC50 concentration, viz., $56.76 \mathrm{ug} / \mathrm{mL}$, showed $67.78 \%$ of cytochrome $C$, respectively, as depicted in Figure 8 and Table 5.

The Cyt-FITC histogram of the gated HepG2 cells distinguished cells at the M1 and M2 phases. (Here M1 refers to negative expression/region and M2 refers to the positive expression/region). Gating of M1 and M2 phases was approximate and refined using software (Cell Quest Software, Version 6.0) analysis.

Table 5. Table showing the \% of cells expressing Cyt C in Untreated, Std, and S. lappa-treated HepG2 cells.

\begin{tabular}{cc}
\hline Cells Group $\Rightarrow$ & \% of Cells Expressed Cytochrome C \\
\hline Cell Control & 0.64 \\
\hline Positive Control & 82.89 \\
\hline S. lappa & 67.78 \\
\hline
\end{tabular}



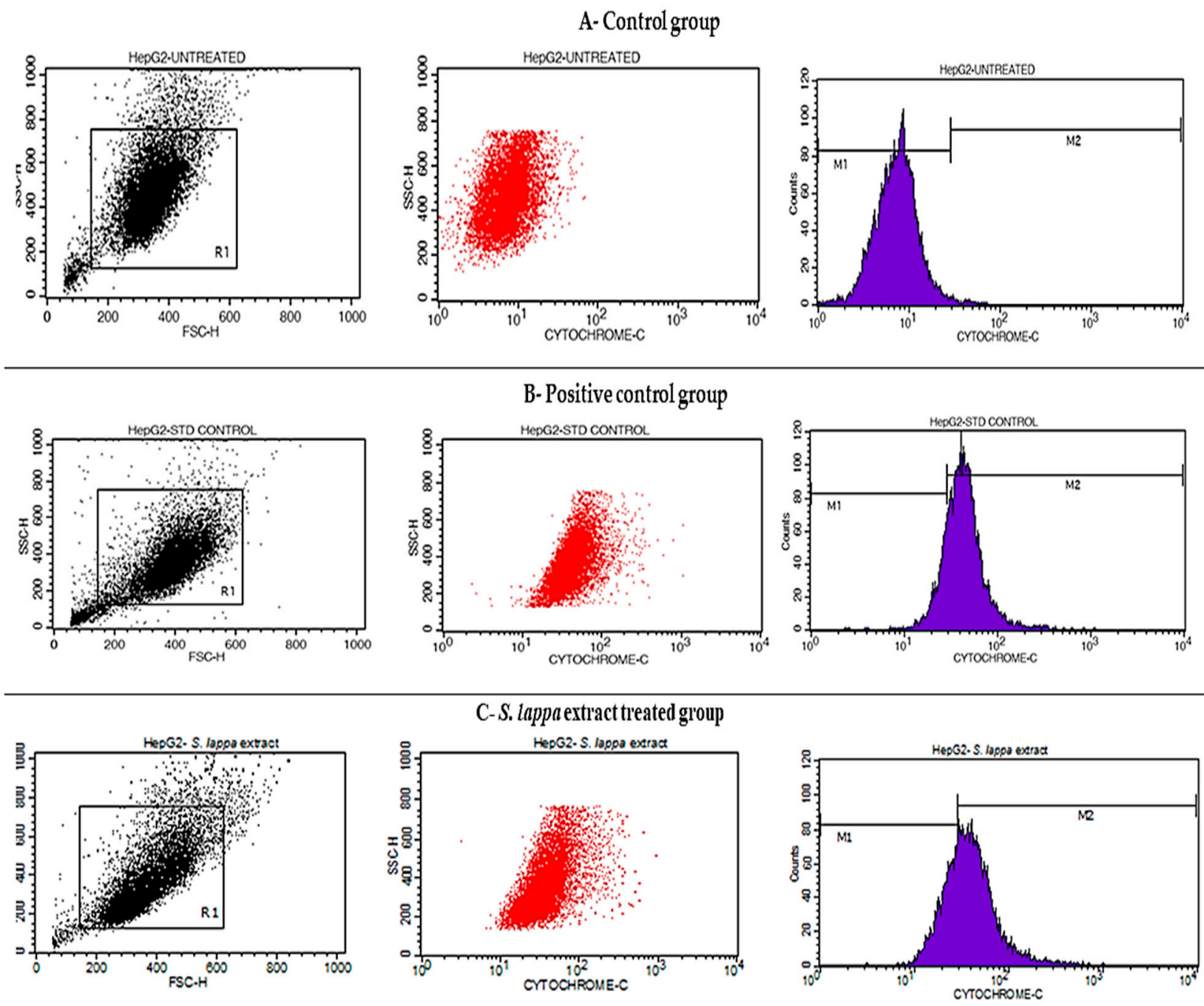

Figure 8. Histograms representing cytochrome C expression study with (A)—control, (B)_positive control-treated, and (C) - S. lappa n-butanol root extract treated with IC50 concentration, viz., $56.76 \mathrm{ug} / \mathrm{mL}$ against the HepG-2 cells using BD FACS Calibur, Cell Quest Pro Software (Version: 6.0).

\subsection{Gene Quantification by $q R T-P C R$}

Our results indicated that the S. lappa n-butanol root extract-treated cells showed increases in the levels of apoptosis-related genes. The obtained results suggest that relative gene expression levels of caspase- 3 and bax genes were up regulated and the anti-apoptotic bcl-2 gene was down regulated in treated groups compared to the untreated group as depicted in Figure 9. GAPDH was used as an internal control in the current study. These results strongly support the apoptosis induction by S. lappa n-butanol root extract in HepG2 cells through the up-regulation of caspase-3 and Bax genes together with a down-regulation of Bcl-2, respectively. Agarose gel electrophoresis image of isolated RNA (Figure S1), validation of primers with each cDNA (Figure S2), melting curves of genes (Figure S3) and amplification curve (Figure S4) are added in supplementary material (S1). 


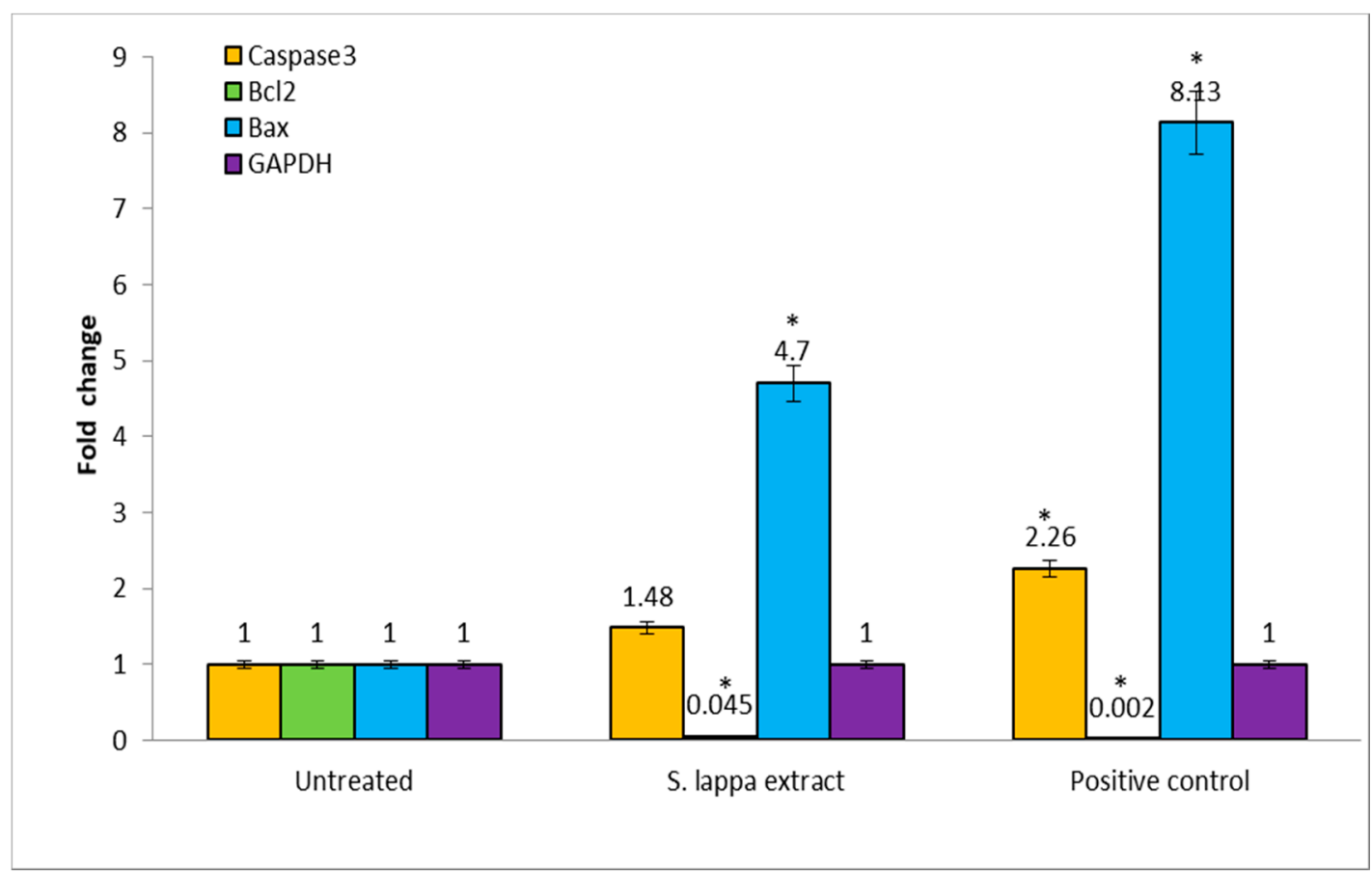

Figure 9. Relative mRNA expression of caspase-3, Bcl-2, Bax, and GAPDH in Untreated, S. lappa extract, and positive control-treated HepG2 cells by RTqPCR. The significant differences from control are indicated by * $p<0.05$.

\section{Discussion}

Hepatocellular carcinoma (HCC) is the fourth most frequent condition of cancer fatality worldwide and the third most common cancer in men [33]. It is the second most prevalent cancer affecting Saudi males [34]. Chemotherapy is a unit of valuable treatment modalities for advanced HCC. It is employed to treat patients who are judged as being unsuitable candidates for surgical resection, local ablative therapy, or transarterial chemoembolization (TACE), which includes patients who have extrahepatic metastasis, show evidence of vascular invasion, or are refractory to TACE [35]. Regarding systemic chemotherapy, sorafenib, a small molecule that inhibits multiple receptor tyrosine kinases (RTKs), is used as the first-line setting for patients with advanced HCC because almost all HCC patients have cirrhosis, chemotherapies, or major resections are not well tolerated. Thus, new strategies for HCC therapy are crucially needed.

In recognition of nature's potential, several plant screenings have performed as potential anticancer drug candidates, and Saussurea lappa is an example of this. In this study, S. lappa root was extracted by chloroform, n-butanol, and ethyl acetate solvent that were characterized by GC-MS in order to obtain the diversity of biologically active phytochemicals. A total of 54 compounds were recorded, out of which most were seen in the $\mathrm{n}$-butanol extract. The results of the present study presented that the $S$. lappa root n-butanol extract exerted anti-oxidant activity along with cytotoxic effects on the HepG2-human hepatocellular adenocarcinoma cancer cell line. We also demonstrated their cell death analysis using nucleic acid-binding dyes, acridine orange and ethidium bromide, which cause fluorescence of cancer cells along with determining their effects on the mitochondrial membrane permeability by the cytochrome $\mathrm{C}$-releasing apoptosis assay and regulation of activity level of genes of bax, bcl-2, and caspase-3.

The GC-MS analysis of the n-butanol S. lappa root extract is depicted in Figure 2. The retention time and the percentage amounts of the compositions are displayed in Table 4. 1,3-Dicaprin (17.3\%), octadecanoic acid,9,10-dihydroxy-,methyl ester (11.5\%), and decanoic acid,1,2,3-propanetriyl ester $(9.4 \%)$ were the primary constituents (Figure 3). The remaining compounds are present in small proportions. 
The anti-oxidative activities of S. lappa n-butanol root extract on both test systems of DPPH free radical scavenging and FRAC increased in a concentration-dependent manner (Figure 4A,B), and therefore it acts as a good source of antioxidant agent. Similar results were seen in the study conducted by Kyung-Mi Chang et al. [36] A previous study showed that costunolide, isolated from the root of S. lappa, is a potent inducer of apoptosis and facilitates its activation via reactive oxygen species generation in HL-60 human leukemia cells [37].

One of the main hallmarks of cancer is cell death evasion [38]. In our study, S. lappa n-butanol root extract displayed potent cytotoxic activity against HepG2 with an IC50 concentration of $56.76 \mu \mathrm{g} / \mathrm{mL}$ (Figures 5 and 6). S.M. Moon et al. reported that S. lappa methanol extract inhibited the growth of KB human oral cancer cells in a dose- and timedependent manner exhibiting IC50 value of $30 \mu \mathrm{g} / \mathrm{mL}$, approximately [39]. This variation in IC50 values may result from usage of $S$. lappa from different geographical sources and growing conditions and having been used on various cell types. Tian et al. (2017) reported that S. lappa ethanol extract shows significant anticancer activity against lymph node carcinoma of the prostate (LNCaP) cancer cells [24].

In the next series of experiments, we carried out acridine orange (AO)-ethidium bromide (EB) double staining cell morphological analysis using the IC50 concentration of $S$. lappa n-butanol root extract against the HepG2 cell line of $56.76 \mu \mathrm{g} / \mathrm{mL}$. Live cells stained uniformly green and can be distinguished from apoptotic cells. Early apoptotic cells will have bright green nuclei and late apoptotic cells display condensed and fragmented orange chromatin, and cells that have died from direct necrosis have structurally normal orange/red nuclei due to co-staining with AO/EB. The treatment group showed fragmented shrunken and marginated nuclei in contrast to the normal and large nucleus in the untreated cells, proving the apoptotic potential of the extract (Figure 7). Similar results were seen in a recent study [40].

In order to determine the potential mechanism by which S. lappa n-butanol root extract causes decreased cell viability, estimation of the cytochrome C-releasing apoptosis assay was done. Release of cytochrome $C$ from the mitochondria to the cytosol is triggered by apoptotic stimuli. In the cytoplasm, the cytochrome $\mathrm{C}$ binds apoptotic protease activating factor, which activates the apoptotic initiator procaspase 9 . Cytosolic cytochrome $\mathrm{C}$ functions in the activation of caspase 3, an ICE family molecule that is a key effector of apoptosis. Untreated HepG2 cells showed very little cytochrome C expression, since there was no apoptosis. The observed percent of cytochrome C-expressed cells in untreated, camptothecin, and $56.76 \mu \mathrm{g} / \mathrm{mL}$ of $S$. lappa n-butanol root extract-treated HepG2 cells were $0.64 \%, 82.89 \%$, and $67.78 \%$, respectively, as seen in Figure 8 . These observations suggest to us that the $S$. lappa n-butanol root extract may have significant apoptosis potential in HepG2 cancer cells with possible therapeutic potential against liver cancer via cytochrome C-mediated apoptosis. Li. et al. demonstrated that beta-lapachone induced rapid release of cytochrome $C$ followed by activation of caspase- 3 in apoptotic cell death in numerous human carcinoma cell lines of the breast cancer cell lines MCF-7, 21 MT, 21 NT, and 21 PT; AD 2780s (human ovary carcinoma); human colon adenocarcinoma cell lines SWI116, HT-29, and DLD; human prostate tumor cells PC-3, DU145, and LNCaP; and human lung carcinoma cell line (G480). This study concluded that beta-lapachone is a potential anti-cancer drug acting on the mitochondrial cytochrome C-caspase pathway [41].

It has been known that caspase family activation represents one of the earliest known steps in the cell death process [42]. Activation of caspase-3 is involved in the regulation of intrinsic and extrinsic apoptotic pathways $[43,44]$. Bcl-2 is a member of a large family of cell survival regulating proteins consisting of both pro- and anti-apoptotic regulators. The bax/bcl-2 regulation is predominant mechanism of apoptosis evasion used by cancers [45]. We therefore assessed the activity level of bax, bcl-2, and caspase- 3 genes. There was relative up-regulation of pro-apoptotic caspase- 3 and bax genes and down-regulation of the antiapoptotic bcl-2 gene in S. lappa n-butanol root extract-treated HepG2 cells compared to the untreated group (Figure 9). Ko et al. reported cytotoxic effects of Saussurea lappa on 
AGS gastric cancer cells, and they determined that there was no effect of S. lappa on bcl-2 expression but had strong stimulating effect on bax gene expression [40]. In line with our study, Moon et al. demonstrated that $S$. lappa extract induced the proteolytic processing of caspase-3, a significant increase of Bax, and marked reduction of Bcl-2 in KB human oral cancer cells [39].

In one of the studies, a methanolic leaf extract of Morus alba that contained rutin, isoquercetin, and various derivatives of kaempferol and quercetin glycosides showed inhibition (IC50 $=33.1 \mu \mathrm{g} / \mathrm{mL}$ ) of HepG2 cells, which was achieved by activation of caspases to induce cell apoptosis and inhibition of topoisomerase II activity [46]. A study conducted by Cho et al reported the anticancer activity in HepG2 cells by isoegomaketone, an essential oil component isolated from Perilla frutescens, when treated for over $24 \mathrm{~h}$, and cleaved caspase-3, caspase-8, and caspase- 9 in a time-dependent and dose-dependent manner [47]. Additionally, Wanga et al. detailed that isoegomaketone inhibited cells and decreased Huh-7 hepatoma cell carcinoma and tumor-xenograft nude mice tumor weight and volume. Isoegomaketone in the concentration of $10 \mathrm{nM} / \mathrm{L}$ decreased pAkt without affecting Akt. Hepatoma cell carcinoma tumor growth was suppressed through PI3K/Akt signaling pathway blocking [48].

GC-MS is a useful and reliable method for the rapid identification of complex plant extracts. In our study, the GC-MS analysis of S. lappa n-butanol extract revealed 27 phytoconstituents including compounds such as $2(3 \mathrm{H})$-benzofuranone,6-ethenylhexahydro-6methylene-7-(1-methylethenyl)-, [3aS- $(3 \mathrm{a} \alpha, 6 \alpha, 7 \beta, 7 \mathrm{a} \beta)]$, commonly known as dehydrosaussurea lactone, with another sesquiterpene lactone costunolide. These compounds have also shown an inhibitory effect against breast cancer cell growth by inducing cell cycle arrest and apoptotic action against cancerous cells, indicating their significant medicinal properties [49]. Wang, et al. showed the molecular anticancer mechanism of oridonin, a tetracyclic terpenoid that is the main active compound in Rabdosiae rubescens in HepG2 cancer cells by G2/cell cycle arrest and apoptosis when applied for $24 \mathrm{~h}$. R. rubescens belongs to the family Lamiaceae and contains important chemical compounds including monoterpenes, sesquiterpene, diterpene, and terpenoids [50]. Moreover, the plant extracts' medicinal effects could be primarily attributed to their secondary products, which act synergistically rather than as single compounds [51]. Thus, it can be concluded that the anticancer and anti-oxidant effects observed in the S. lappa extract are linked with the presence of these different compounds.

\section{Conclusions}

The $S$. lappa n-butanol extract demonstrated anti-proliferation capacity against the HepG2 cancer cell line successfully by inducing cell death. Our study showed the potential role of S. lappa in activating apoptosis causing dose-dependent increases in early and late apoptosis cell populations. Moreover, apoptosis initiation induced by S. lappa was confirmed by cytochrome C-mediated apoptosis through increased mitochondrial membrane permeability, causing cytochrome $\mathrm{C}$ release and upregulation of apoptosis gene markers in HepG2 cancer cells. This study provides preliminary data that propose S. lappa as a valuable source of potentially new natural anti-hepatic cancer compound(s) that act by triggering apoptotic cell death. Further research is required to find effective compounds as well as the cellular and molecular mechanisms involved.

Supplementary Materials: The following are available online at https:/ / www.mdpi.com/article/10 .3390/cimb43020079/s1. Figure S1: Agarose gel electrophoresis image of Isolated RNA, Figure S2: Validation of primers with each cDNA, Figure S3 Melting curves of genes. Melting temperatures were visualized by plotting the negative first derivative of fluorescence relative to the temperature in Celsius [-(d/dT)] and Figure S4: Amplification curve. 
Author Contributions: Conceptualization, A.A.A. and A.B.; Funding acquisition, A.A.A., A.B. and R.A.A.; Investigation, A.A.A. and A.B.; Methodology, A.A.A., A.B. and S.N.; Project administration, A.B. and S.K.N. (Shaik Kalimulla Niazi); Validation, M.R., S.K.N. (Shashiraj Kareyellapa Nagaraja) and M.P.B.; Visualization, S.N.; Writing-original draft, S.K.N. (Shaik Kalimulla Niazi) and A.B.; Writing-review and editing, R.A.A., S.K.N. (Shaik Kalimulla Niazi), S.N., M.R., S.K.N. (Shashiraj Kareyellapa Nagaraja) and M.P.B. All authors have read and agreed to the published version of the manuscript.

Funding: This research was funded by the Deanship of Scientific Research at Princess Nourah bint Abdulrahman University, through the Research Funding Program, Grant Number (FRP-1441-10).

Institutional Review Board Statement: Ethical approval was taken before the start of the study by the Institutional Review Board of Princess Nourah bint Abdulrahman University with Registration number of H-01-R-059 and IRB log number, 19-0276.

Informed Consent Statement: Not applicable.

Data Availability Statement: The raw data used and/or analyzed during the current study will be available from the corresponding author on reasonable request.

Conflicts of Interest: The authors declare that there is no conflict of interest of this study.

\section{References}

1. Parkin, D.M.; Bray, F.; Ferlay, J.; Pisani, P. Global cancer statistics, 2002. CA Cancer J. Clin. 2005, 55, 74-108. [CrossRef]

2. Bruix, J.; Sherman, M.; Llovet, J.M.; Beaugrand, M.; Lencioni, R.; Burroughs, A.K.; Christensen, E.; Pagliaro, L.; Colombo, M.; Rodes, J. Clinical management of hepatocellular carcinoma. Conclusions of the Barcelona-2000 EASL conference. European Association for the Study of the Liver. J. Hepatol. 2001, 35, 421-430. [CrossRef]

3. Llovet, J.M.; Burroughs, A.; Bruix, J. Hepatocellular carcinoma. Lancet 2003, 362, 1907-1917. [CrossRef]

4. Villanueva, A.; Llovet, J.M. Targeted therapies for hepatocellular carcinoma. Gastroenterology. 2011, 140, 1410-1426. [CrossRef]

5. Llovet, J.M.; Ricci, S.; Mazzaferro, V.; Hilgard, P.; Gane, E.; Blanc, J.F.; de Oliveira, A.C.; Santoro, A.; Raoul, J.L.; Forner, A.; et al. Sorafenib in advanced hepatocellular carcinoma. N. Engl. J. Med. 2008, 359, 378-390. [CrossRef]

6. Bindseil, K.U.; Jakupovic, J.; Wolf, D.; Lavayre, J.; Leboul, J.; van der Pyl, D. Pure compound libraries; a new perspective for natural product based drug discovery. Drug Discov Today. 2001, 6, 840-847. [CrossRef]

7. Lin, X.; Peng, Z.; Su, C. Potential anti-cancer activities and mechanisms of costunolide and dehydrocostuslactone. Int. J. Mol. Sci. 2015, 16, 10888-10906. [CrossRef] [PubMed]

8. Pan, L.; Chai, H.; Kinghorn, A.D. The continuing search for antitumor agents from higher plants. Phytochem. Lett. 2010, 3, 1-8. [CrossRef] [PubMed]

9. Pandey, M.M.; Rastogi, S.; Rawat, A.K. Saussurea costus: Botanical, chemical and pharmacological review of an ayurvedic medicinal plant. J. Ethnopharmacol. 2007, 110, 379-390. [CrossRef] [PubMed]

10. Chhabra, B.; Gupta, S.; Jain, M.; Kalsi, P. Sesquiterpene lactones from Saussurea lappa. Phytochemistry 1998, 49, 801-804. [CrossRef]

11. Yang, W.; Chen, X.; Li, Y.; Guo, S.; Wang, Z.; Yu, X. Advances in Pharmacological Activities of Terpenoids. Nat. Prod. Commun. 2020, 15, 1934578X20903555. [CrossRef]

12. Andrade, L.N.; Lima, T.C.; Amaral, R.G.; Pessoa, C.D.Ó.; Filho, M.O.d.M.; Soares, B.M.; Nascimento, L.G.d.; Carvalho, A.A.; De Sousa, D.P. Evaluation of the Cytotoxicity of Structurally Correlated p-Menthane Derivatives. Molecules 2015, 20, 13264-13280. [CrossRef] [PubMed]

13. Gai, W.T.; Yu, D.P.; Wang, X.S.; Wang, P.T. Anti-cancer effect of ursolic acid activates apoptosis through ROCK/PTEN mediated mitochondrial translocation of cofilin-1 in prostate cancer. Oncol. Let. Oncol. Lett. 2016, 12, 2880-2885. [CrossRef] [PubMed]

14. Duangmano, S.; Dakeng, S.; Jiratchariyakul, W.; Suksamrarn, A.; Smith, D.R.; Patmasiriwat, P. Antiproliferative effects of cucurbitacin B in breast cancer cells: Down-regulation of the c-Myc/hTERT/telomerase pathway and obstruction of the cell cycle. Int. J. Mol. Sci. 2010, 11, 5323-5338. [CrossRef] [PubMed]

15. Zhu, X.-Y.; Guo, D.-W.; Lao, Q.-C.; Xu, Y.-Q.; Meng, Z.-K.; Xia, B.; Yang, H.; Li, C.-Q.; Li, P. Sensitization and synergistic anti-cancer effects of Furanodiene identified in zebrafish models. Sci. Rep. 2019, 9, 4541. [CrossRef]

16. Chadwick, M.; Trewin, H.; Gawthrop, F.; Wagstaff, C. Sesquiterpenoids lactones: Benefits to plants and people. Int. J. Mol. Sci. 2013, 14, 12780-12805. [CrossRef]

17. Kretschmer, N.; Rinner, B.; Stuendl, N.; Kaltenegger, H.; Wolf, E.; Kunert, O.; Boechzelt, H.; Leithner, A.; Bauer, R.; Lohberger, B. Effect of costunolide and dehydrocostus lactone on cell cycle, apoptosis, and ABC transporter expression in human soft tissue sarcoma cells. Planta Medica 2012, 78, 1749-1756. [CrossRef]

18. Sun, C.M.; Syu, W.J.; Don, M.J.; Lu, J.J.; Lee, G.H. Cytotoxic sesquiterpene lactones from the root of Saussurea lappa. J. Nat. Prod. 2003, 66, 1175-1180. [CrossRef]

19. Yoshikawa, M.; Hatakeyama, S.; Inoue, Y.; Yamahara, J. Saussureamines A, B, C, D, and E, new anti-ulcer principles from Chinese Saussureae Radix. Chem. Pharm. Bull. 1993, 41, 214-216. [CrossRef] 
20. Chen, H.C.; Chou, C.K.; Lee, S.D.; Wang, J.C.; Yeh, S.F. Active compounds from Saussurea lappa Clarks that suppress hepatitis B virus surface antigen gene expression in human hepatoma cells. Antivir. Res. 1995, 27, 99-109. [CrossRef]

21. Tabata, K.; Nishimura, Y.; Takeda, T.; Kurita, M.; Uchiyama, T.; Suzuki, T. Sesquiterpene lactones derived from Saussurea lappa induce apoptosis and inhibit invasion and migration in neuroblastoma cells. J. Pharmacol Sci. 2015, 127, 397-403. [CrossRef] [PubMed]

22. Hung, J.Y.; Hsu, Y.L.; Ni, W.C.; Tsai, Y.M.; Yang, C.J.; Kuo, P.L.; Huang, M.S. Oxidative and endoplasmic reticulum stress signaling are involved in dehydrocostuslactone-mediated apoptosis in human non-small cell lung cancer cells. Lung Cancer 2010, 68, 355-365. [CrossRef]

23. Kim, H.R.; Kim, J.M.; Kim, M.S.; Hwang, J.K.; Park, Y.J.; Yang, S.H.; Kim, H.J.; Ryu, D.G.; Lee, D.S.; Oh, H.; et al. Saussurea lappa extract suppresses TPA-induced cell invasion via inhibition of NF-kappaB-dependent MMP-9 expression in MCF-7 breast cancer cells. BMC Complement. Altern Med. 2014, 14, 170. [CrossRef]

24. Tian, X.; Song, H.S.; Cho, Y.M.; Park, B.; Song, Y.J.; Jang, S.; Kang, S.C. Anticancer effect of Saussurea lappa extract via dual control of apoptosis and autophagy in prostate cancer cells. Medicine 2017, 96, e7606. [CrossRef]

25. Ong, E.S. Extraction methods and chemical standardization of botanicals and herbal preparations. J. Chromatogr. B Analyt. Technol. Biomed. Life Sci. 2004, 812, 23-33. [CrossRef]

26. Khandelwal, K.R. Practical Pharmacognosy; Pragati Books Pvt. Ltd.: Pune, India, 2008.

27. Kokate, C.; Purohit, A.; Gokhale, S. Carbohydrate and derived Products, drugs containing glycosides, drugs containing tannins, lipids and protein alkaloids. Text. Book Pharmacogn. 2001, 7, 133-166.

28. Gwari, G.; Bhandari, U.; Andola, H.C.; Lohani, H.; Chauhan, N. Volatile constituents of Saussurea costus roots cultivated in Uttarakhand Himalayas, India. Pharmacogn. Res. 2013, 5, 179-182.

29. Sahoo, S.; Ghosh, G.; Das, D.; Nayak, S. Phytochemical investigation and in vitro antioxidant activity of an indigenous medicinal plant Alpinia nigra B.L. Burtt. Asian Pac. J. Trop Biomed. 2013, 3, 871-876. [CrossRef]

30. Cory, A.H.; Owen, T.C.; Barltrop, J.A.; Cory, J.G. Use of an aqueous soluble tetrazolium/formazan assay for cell growth assays in culture. Cancer Commun. 1991, 3, 207-212. [CrossRef]

31. Aithal, B.K.; Kumar, M.R.; Rao, B.N.; Udupa, N.; Rao, B.S. Juglone, a naphthoquinone from walnut, exerts cytotoxic and genotoxic effects against cultured melanoma tumor cells. Cell Biol. Int. 2009, 33, 1039-1049. [CrossRef] [PubMed]

32. Waterhouse, N.J.; Trapani, J.A. A new quantitative assay for cytochrome c release in apoptotic cells. Cell Death Differ. 2003, 10, 853-855. [CrossRef]

33. McGlynn, K.A.; London, W.T. Epidemiology and natural history of hepatocellular carcinoma. Best Pr. Res. Clin. Gastroenterol. 2005, 19, 3-23. [CrossRef]

34. Abdo, A.; Al Abdul Karim, H.; Al Fuhaid, T.; Sanai, F.; Kabbani, M.; Al Jumah, A.; Burak, K. Saudi gastroenterology association guidelines for the diagnosis and management of hepatocellular carcinoma: Summary of recommendations. Saudi J. Gastroenterol. 2007, 13, 45-48. [CrossRef] [PubMed]

35. Abdo, A.A.; Hassanain, M.; AlJumah, A.; Al Olayan, A.; Sanai, F.M.; Alsuhaibani, H.A.; Abdulkareem, H.; Abdallah, K.; AlMuaikeel, M.; Al Saghier, M.; et al. Saudi guidelines for the diagnosis and management of hepatocellular carcinoma: Technical review and practice guidelines. Ann. Saudi Med. 2012, 32, 174-199. [CrossRef] [PubMed]

36. Chang, K.M.; Choi, S.I.; Kim, G.H. Anti-oxidant Activity of Saussurea lappa C.B. Clarke Roots. Prev. Nutr. Food Sci. 2012, 17, 306-309. [CrossRef] [PubMed]

37. Lee, M.G.; Lee, K.T.; Chi, S.G.; Park, J.H. Costunolide induces apoptosis by ROS-mediated mitochondrial permeability transition and cytochrome C release. Biol. Pharm. Bull. 2001, 24, 303-306. [CrossRef]

38. Hanahan, D.; Weinberg, R.A. Hallmarks of cancer: The next generation. Cell 2011, 144, 646-674. [CrossRef]

39. Moon, S.M.; Yun, S.J.; Kook, J.K.; Kim, H.J.; Choi, M.S.; Park, B.R.; Kim, S.G.; Kim, B.O.; Lee, S.Y.; Ahn, H.; et al. Anticancer activity of Saussurea lappa extract by apoptotic pathway in KB human oral cancer cells. Pharm. Biol. 2013, 51, 1372-1377. [CrossRef]

40. Shati, A.A.; Alkahtani, M.A.; Alfaifi, M.Y.; Elbehairi, S.E.I.; Elsaid, F.G.; Prasanna, R.; Mir, M.A. Secondary Metabolites of Saussurea costus Leaf Extract Induce Apoptosis in Breast, Liver, and Colon Cancer Cells by Caspase-3-Dependent Intrinsic Pathway. BioMed Res. Int. 2020, 2020, 1608942. [CrossRef]

41. Li, Y.Z.; Li, C.J.; Pinto, A.V.; Pardee, A.B. Release of mitochondrial cytochrome C in both apoptosis and necrosis induced by beta-lapachone in human carcinoma cells. Mol. Med. 1999, 5, 232-239. [CrossRef]

42. Cohen, G.M. Caspases: The executioners of apoptosis. Biochem. J. 1997, 326, 1-16. [CrossRef]

43. Green, D.R.; Reed, J.C. Mitochondria and apoptosis. Science 1998, 281, 1309-1312. [CrossRef]

44. Liu, X.; Zou, H.; Slaughter, C.; Wang, X. DFF, a heterodimeric protein that functions downstream of caspase-3 to trigger DNA fragmentation during apoptosis. Cell 1997, 89, 175-184. [CrossRef]

45. Rajabi, S.; Maresca, M.; Yumashev, A.V.; Choopani, R.; Hajimehdipoor, H. The Most Competent Plant-Derived Natural Products for Targeting Apoptosis in Cancer Therapy. Biomolecules 2021, 11, 534. [CrossRef]

46. Naowaratwattana, W.; De-Eknamkul, W.; De Mejia, E.G. Phenolic-containing organic extracts of mulberry (Morus alba L.) leaves inhibit HepG2 hepatoma cells through G2/M phase arrest, induction of apoptosis, and inhibition of topoisomerase II $\alpha$ activity. J. Med. Food 2010, 13, 1045-1056. [CrossRef] 
47. Cho, B.O.; Jin, C.H.; Park, Y.D.; Ryu, H.W.; Byun, M.W.; Seo, K.I.; Jeong, I.Y. Isoegomaketone induces apoptosis through caspase-dependent and caspase-independent pathways in human DLD1 cells. Biosci. Biotechnol. Biochem. 2011, 75, $1306-1311$. [CrossRef]

48. Wang, Y.; Huang, X.; Han, J.; Zheng, W.; Ma, W. Extract of Perilla frutescens inhibits tumor proliferation of HCC via PI3K/AKT signal pathway. Afr. J. Tradit. Complement. Altern. Med. 2013, 10, 251-257. [CrossRef] [PubMed]

49. Peng, Z.; Wang, Y.; Fan, J.; Lin, X.; Liu, C.; Xu, Y.; Ji, W.; Yan, C.; Su, C. Costunolide and dehydrocostuslactone combination treatment inhibit breast cancer by inducing cell cycle arrest and apoptosis through c-Myc/p53 and AKT/14-3-3 pathway. Sci. Rep. 2017, 7, 41254. [CrossRef] [PubMed]

50. Wang, H.; Ye, Y.; Pan, S.Y.; Zhu, G.Y.; Li, Y.W.; Fong, D.W.; Yu, Z.L. Proteomic identification of proteins involved in the anticancer activities of oridonin in HepG2 cells. Phytomedicine 2011, 18, 163-169. [CrossRef] [PubMed]

51. Jigna, P.; Rathish, N.; Sumitra, C. Preliminary screening of some folklore medicinal plants from western India for potential antimicrobial activity. Indian J. Pharmacol. 2005, 37, 408. 